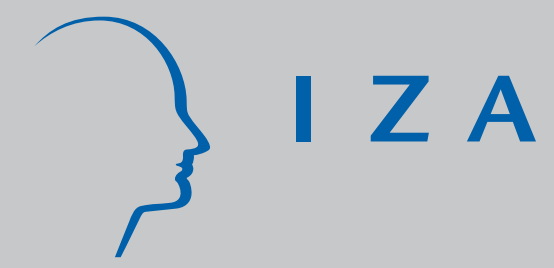

IZA DP No. 1055

Agglomeration Effects on Employer-Provided Training: Evidence from the UK

Giorgio Brunello

Francesca Gambarotto

March 2004 


\title{
Agglomeration Effects on Employer-Provided Training: Evidence from the UK
}

\author{
Giorgio Brunello \\ University of Padua, \\ CESifo and IZA Bonn \\ Francesca Gambarotto \\ University of Padua

\section{Discussion Paper No. 1055 \\ March 2004}

\author{
IZA \\ P.O. Box 7240 \\ 53072 Bonn \\ Germany \\ Phone: +49-228-3894-0 \\ Fax: +49-228-3894-180 \\ Email: iza@iza.org
}

\begin{abstract}
Any opinions expressed here are those of the author(s) and not those of the institute. Research disseminated by IZA may include views on policy, but the institute itself takes no institutional policy positions.
\end{abstract}

The Institute for the Study of Labor (IZA) in Bonn is a local and virtual international research center and a place of communication between science, politics and business. IZA is an independent nonprofit company supported by Deutsche Post World Net. The center is associated with the University of Bonn and offers a stimulating research environment through its research networks, research support, and visitors and doctoral programs. IZA engages in (i) original and internationally competitive research in all fields of labor economics, (ii) development of policy concepts, and (iii) dissemination of research results and concepts to the interested public.

IZA Discussion Papers often represent preliminary work and are circulated to encourage discussion. Citation of such a paper should account for its provisional character. A revised version may be available on the IZA website (www.iza.org) or directly from the author. 
IZA Discussion Paper No. 1055

March 2004

\section{ABSTRACT \\ Agglomeration Effects on Employer-Provided Training: Evidence from the UK*}

Recent empirical evidence suggests that the density of local economic activity - measured as the number of employees per squared kilometer - positively affects local average productivity. In this paper we use British data from the European Community Household Panel to ask whether local density affects employer-provided training. We find that training is less frequent in economically denser areas. We explain this result as the outcome of the interaction between the positive pooling effects and negative poaching and turnover effects of agglomeration. The size of the negative effect of density is not negligible: when evaluated at the average firm size in the local area, a 10 percent increase in density reduces the probability of employer-provided training by 0.07 , more than 20 percent of the average incidence of training in the UK during the sample period.

JEL Classification: J24, R12

Keywords: $\quad$ training, spatial economics, Britain

Corresponding author:

Giorgio Brunello

Department of Economics

University of Padova

Via del Santo 33

35100 Padova

Italy

Email: giorgio.brunello@unipd.it

\footnotetext{
* We are grateful to Andrea Bassanini, Federico Cingano, Piero Cipollone, Maria De Paola, Peter Dolton and the audience in seminars at Paris II and the Bank of Italy for comments and suggestions. The ECHP data used in this paper are from the 2003 release (contract 14/99 with the Department of Economics, University of Padua). The usual disclaimer applies.
} 


\section{Introduction}

Does spatial agglomeration affect employer provided training? When labor economists analyze the training decision, they usually overlook spatial factors, in spite of the relevance of the spatial agglomeration literature. The usual line of approach is that firms decide to invest in human capital when they can hold the trained worker and profit of her higher productivity, i.e. when the poaching risk is low. Poaching occurs because the skills learnt in a single firm are not wholly specific to that firm, but can be transferred to some extent to competitors. In most circumstances, the risk of poaching depends both on the type of skill and on the presence of local competitors, who can find it profitable to hire the trained employee. In Silicon Valley, a trained employee can just walk down the street and pick up a new and better paid job. If competitors are located far away, however, it takes a long walk to locate a better job, and some workers may be discouraged by the expected mobility costs.

If we take a local labor market perspective, it is clear that dense labor markets, with more workers and more firms, present better opportunities to locate a better job than sparse labor markets. The risk of poaching implies that agglomerated firms face an uncertain return to training and tend to under-invest in human capital. At the same time, however, local density has also advantages for training firms. Local labor pooling as a Marshallian externality improves knowledge spillovers and productivity and favors the matching of labor supply and demand. Turnover is usually higher in agglomerated areas. Knowledge and new ideas are embodied in skilled workers, and labor pooling facilitates labor mobility within areas and the diffusion of knowledge. Since skills and technical knowledge are complements, productivity increases faster for skilled workers, with positive effects on the returns to training in denser areas.

It follows that firms, when deciding to train, need to balance the positive pooling effects, in terms of higher productivity, with the higher risk of poaching. When we compare similar firms in local labor markets with different density, this trade-off implies that (employer - provided) training incidence can be higher, or lower, in denser areas, depending on the relative weight of pooling and poaching effects. Local density, the intensity of local competition, the local economic structure and endowment of human capital are key elements in the training choice.

This paper is an empirical investigation of the relationship between local economic density and employer - provided training in UK Nuts 2 groups of counties using longitudinal ECHP (European Community Household Panel) data for the period 1994-2000. While we are not aware of any empirical study which addresses the same issue, our research is closely related to the growing 
number of studies which focus on the relationship between local economic density and productivity, starting with Hall and Ciccone [1996].

As shown in Figure 1, which plots the percentage of trained employees in 34 Nuts 2 local areas of the UK for 1997, the incidence of employer - provided training varies significantly across local labor markets. Regions with higher than average training levels are mainly urban areas: Greater London, the South East (Essex, Kent, Brighton) and the South West (Southampton, Oxford), the regions of Manchester and the West Midlands. Figure 2 plots training incidence against employment density in each area, measured as the log of the number of employees in the private sector per squared kilometer. Density is a measure of proximity, and has been used by Hall and Ciccone [1996] to capture the positive pooling externalities associated to close and repeated interactions among economic agents. Inspection of the figure does not reveal any clear pattern, but obviously a significant relationship could be obscured by the presence of numerous confounding effects, such as the industrial and occupational composition of labor, the average level of educational attainment and else.

The paper is organized as follows. Section 1 contains a brief summary of the relevant literature, with special emphasis on agglomeration effects. Section 2 introduces an illustrative model. Section 3 presents the empirical specification and Section 4 illustrates the data. The last two sections discuss the main results and some robustness exercises. Conclusions follow.

\section{A Brief Summary of the Literature}

Standard economic theory suggests that employers invest in training up to the point where marginal private benefits are equal to marginal private costs. The key benefit of training is the increase in labor productivity. Marginal costs include both direct and opportunity costs. The willingness of firms to pay for training depends on its degree of transferability. As argued by Becker [1964] in his classical study on human capital, the cost of general training is entirely borne by the employee if labor markets are perfectly competitive, because in this case the accumulated skills can be fully transferred to other firms. Imperfect labor markets reduce the transferability of general skills and the poaching threat and can induce firms to bear some or all the costs of training (see Acemoglu and Pischke [1999]). By definition, firm - specific training cannot be fully transferred, and its costs and revenues are shared by the parties.

The bottom line of our paper is that the economic features of the local labor market where the firm operates can affect the marginal costs and benefits of employer - provided training. On the one hand, the density and specialization of economic activity produce positive pooling effects that affect 
marginal benefits. On the other hand, the higher poaching opportunities in more agglomerated local areas, associated to higher labor turnover, reduce the expected benefits of employer - provided training.

In this section we briefly summarize - without pretending to be exhaustive - how the labor pooling and poaching effects have been treated in the spatial agglomeration literature. Labor market pooling as a Marshallian externality plays a crucial role in the location and spatial agglomeration theory of Krugman [1991]. In this literature, geographical concentration produces spatial increasing returns and has a positive impact on the production / diffusion of technological innovation and knowledge (Audretsch and Feldman, [2003]). Labor pooling occurs when the spatial concentration of workers fosters job turnover and improves the match between demand and supply, thus favoring the diffusion of ideas and increasing the productivity of firms located in the area (Rosenthal and Strange [2004]). The knowledge spillovers typical of agglomerated areas are closely linked to labor pooling because knowledge is partly embodied in workers and its diffusion is driven by labor turnover (Combes and Duranton [2001]).

Particular attention has been given in this literature to the impact of knowledge externalities on the growth of cities. Glaeser et al. [1992] distinguish three types of local externalities: MAR (Marshall-Arrow-Romer) externalities, driven by industrial specialization, Porter externalities, originated by specialization and strong competition among local firms, and Jacobs externalities, i.e. knowledge spillovers from diversity in the structure of local production. Their empirical evidence shows that urban productivity growth is increased by diversity and reduced by specialization. Henderson et al. [1995] observes that knowledge spillovers play a different role in traditional and high-tech industries and in different stages of growth. In high-tech sectors, Jacobs externalities stimulate growth when location takes place and MAR externalities are important for location persistence. In traditional sectors only MAR externalities are relevant.

Ciccone and Hall (1996) and Ciccone (2002) study the relationship between local economic density - measured as the number of employees per squared kilometer - and productivity and find that productivity is higher in denser areas, both in Europe and in the US. The density of economic activity positively affects productivity by reducing transportation costs, by increasing the interaction of firms because of proximity and by fostering knowledge spillovers. Rosenthal e Strange [2001] address the causes of agglomeration by estimating the Ellison and Glaeser [1997] concentration index, which distinguishes random concentration from concentration with agglomeration externalities, and by regressing the index on agglomeration factors, such as labor market pooling, input sharing and knowledge spillovers. They do so for different spatial levels zipcode, county and state - and find that labor market pooling is the only agglomeration factor statistically significant in each geographical level. In their attempt to explain the urban wage 
premium, Glaeser and Maré [2000] observe that labor matching works better in economically dense areas, such as cities. In addition, cities provide opportunities for higher levels of interaction among agents, which fosters the accumulation of human capital. Moreover, the skill endowments of workers in urban areas is quickly updated because the local context facilitates the learning process.

These studies suggest that spatial agglomeration and labor pooling affect positively local productivity. Local density, however, has also economic disadvantages that reduce the incentive of firms to train. Since local concentration facilitates labor turnover and stimulates poaching activities, firms in denser areas can hire more easily skilled workers and save the cost of training unskilled employees. The incentive to train in these areas is also reduced by the higher risk of losing the trained employee. When the threat of poaching is too strong and there is harsh competition for skilled workers, firms can even decide to relocate in a less dense area. Almazan et al. [2003] suggest that relocation can be profitable for high tech firms operating in science-based industries. For these firms the investment in human capital is crucial for production and the poaching risk need to be minimized, not only because it reduces the expected benefits of training, but also because it becomes a powerful vehicle of diffusion to competitors of new developed ideas and techniques (Combes and Duranton [2001]).

\section{An Illustrative Model}

We illustrate the relationship between employer - provided training and agglomeration effects using the model developed by Stevens [1995] ${ }^{1}$. Consider a two - period economy populated by two identical firms. The productivity (and wages) of unskilled employees is normalized to zero. Individual productivity can be increased to $v>0$ by employer - provided training. Training is general and occurs during the first period. At the start of the second period firms compete for trained employees and production takes place. There are no mobility costs and the labor market is perfectly competitive. The training decision of each firm is conditioned by the possibility that the trained employee can be poached by the other firm at the start of the production period. This affects wage policy. Let training costs $C(N, X)$ be a convex function of the number of trainees $N$, where $X$ is a shift variable - such as for example local labor market conditions -, which influences training costs. Since training is general, trained workers are equally productive in either firm. The wage $w_{i}, i$ $=1,2$, paid by firms 1 and 2 to trained employees, is the outcome of a Bertrand game. Therefore $w_{1}=w_{2}=w$. The common wage $w$ is equal to productivity $v$. To see why, imagine that one firm

\footnotetext{
${ }^{1}$ See also Booth, Francesconi and Zoega [1999]
} 
sets the wage below productivity. With no mobility costs and perfect transferability of training, this firm will lose all its employees to the other firm, which can make a profit by setting wages a $\varepsilon$ higher but still below productivity. The socially optimal level of training requires

$$
C^{\prime}(N, X)=v
$$

where the prime is for the first derivative with respect to $N$.

Define $\Phi\left(w_{1}-w_{2}\right)$ as the share of trained workers employed by firm 1, where $\Phi$ is the standard normal distribution. Without labor market imperfections, when $w_{1}>w_{2}$ the probability $\Phi\left(w_{1}-w_{2}\right)$ is equal to 1 and all trained employees work in firm 1 . Since $w_{1}=w_{2}$ in the equilibrium of the Bertrand game, $\Phi(0)=\frac{1}{2}$ by symmetry of the normal distribution. Random allocation implies that in equilibrium half of the trained workers are employed in firm 1 and the other half in firm 2.

Now suppose that the skilled labor market is not perfectly competitive (see Acemoglu and Pischke [1999]). Following Stevens, assume that there is some stickiness in the movement of workers between firms, so that “...if one firm's wage is a little above the other, not all workers will necessarily prefer to work for the higher wage firm.." (Stevens [1995], p.32). Stickiness can be due to search frictions, asymmetric information, labor market institutions, local amenities, transportation costs and loyalty and reciprocity in the employment relationship.

With positive stickiness, the retention probability of a trained worker when the outside wage is higher than the inside wage is strictly higher than zero, so that $0<\Phi\left(w_{1}-w_{2}\right)<1$ when $w_{1}>w_{2}$. When the wage in firm 1 is higher than in firm 2, a share $1-\Phi\left(w_{1}-w_{2}\right)>0$ of trained employees remain with the latter firm.

At the start of the second period each firm chooses the wage paid to trained employees by maximizing profits net of training costs, which are bygones. (Real) profits are given by

$$
\begin{aligned}
& \Pi_{1}=\left(v-w_{1}\right) \Phi\left(w_{1}-w_{2}\right) N \\
& \Pi_{2}=\left(v-w_{2}\right)\left[1-\Phi\left(w_{1}-w_{2}\right)\right] N
\end{aligned}
$$

Defining $x=w_{1}-w_{2}$, the first order conditions for a maximum can be written as

$$
x \phi(x)=1-2 \Phi(x)
$$

where $\phi$ is the density function. Clearly, the above condition is satisfied for $x=0$. Therefore

$$
w_{1}=w_{2}=w=v-\frac{\Phi(0)}{\phi(0)}=v-k
$$

Because of labor market imperfections, wages can be lower than productivity even when training is fully general. Therefore, firms may be willing to pay for training costs (see Acemoglu and Pischke [1999]). The training decision is the outcome of a Cournot game, where each firm internalizes the wage setting function (5) and sets the number of trained employees by taking the 
number trained by the other firm as given. When all the training costs are born by firms, the number of trained workers is obtained by maximizing

$$
\Pi_{i}=k \frac{\sum_{i} N_{i}}{2}-C\left(N_{i}, X\right) \quad i=1,2
$$

with respect to $N_{i}$. The optimal condition is

$$
C^{\prime}\left(N_{i}, X\right)=\frac{k}{2}
$$

If workers pay part of the cost, and this part $p$ is proportional to productivity after training

$$
p=\alpha v
$$

the optimal condition becomes

$$
C^{\prime}\left(N_{i}, X\right)=\alpha v+\frac{1}{2} k
$$

The variable $k$ is an indicator of the degree of labor market imperfection. A higher degree of labor market imperfection increases employer - provided training by raising marginal benefits. Training is also higher when labor productivity and the share of the costs borne by employees increase.

\subsection{Agglomeration effects}

The illustrative model considers a single labor market but can be extended to cover a collection of local labor markets by assuming that labor mobility takes place mainly if not exclusively within properly defined local areas ${ }^{2}$. By taking a local labor market approach we can ask whether the training decisions of employers are affected by the conditions of the specific labor market where both firms and employees are located.

As reviewed in Section 1 of the paper, a key tenet of the new economic geography is that localization economies are important for productivity and growth. The higher proximity of individuals and firms in dense economic areas increases knowledge spillovers and fosters technological progress (Ciccone and Hall [1996]). As a result, productivity increases. This increase is more significant for skilled employees, because of the complementarity between technical progress, innovation and skills (Acemoglu [2000]).

Recent applications of economic geography models to local labor markets have explained the localization decisions of firms with the trade off between positive pooling effects and negative poaching effects (see Combes and Duranton [2001]). In dense economic areas - with a relatively

\footnotetext{
${ }^{2}$ See Zenou [2003] for a theory of urban labor markets.
} 
high concentration of workers and firms - labor market pooling improves the matching of workers and firms and facilitates the transmission of knowledge and innovative activities. As a result expected labor productivity increases, which encourages localization. On the other hand, the risk of poaching is higher in dense areas. Since knowledge is partly embodied in workers, this risk discourages localization.

We argue in this paper that the trade-off between pooling and poaching effects not only influences the localization decisions of firms and their productivity, but also their willingness to train employees. On the one hand, firms located in dense local labor markets have higher incentives to train because skilled workers are more productive. On the other hand, trained employees can be poached by competitors more easily in dense markets (Alzaman et al. [2003]), which also provide better opportunities to fill skilled vacancies by hiring rather than by training. Higher poaching risks and better hiring opportunities reduce the incentive to train in-house.

Letting $D$ be local labor market density, measured as the number of employees per squared kilometer, it is useful to re-write the first order condition (9) as follows

$$
C^{\prime}(N, D)=\alpha(D) v(D)+\frac{1}{2} k(D)
$$

As argued by Ciccone and Hall, density positively affects productivity $v$ in three ways: transportation costs which increase with distance, externalities associated with the physical proximity of production (localization or urban externalities) and a higher degree of beneficial specialization. Therefore $\frac{\partial v}{\partial D}>0$. If denser labor markets are more competitive, workers are more willing to pay a higher share of the training cost a, which they can recoup more easily. Hence $\frac{\partial \alpha}{\partial D}>0$. The marginal costs of training can also be affected by density: on the one hand, denser labor markets improve the average quality of the pool of applicants. If abler workers are cheaper to train, marginal costs decline. On the other hand, the opportunity costs of training are higher in denser areas, because productivity is higher. It follows that the overall effect of $\mathrm{D}$ on $C^{\prime}(N, D)$ is uncertain.

Acemoglu and Pischke [1999] argue that the monopsonistic power of the local employer declines with the probability of re-employment. Since denser areas offer better matching opportunities and a higher probability of re-employment, employers located in these areas have, ceteris paribus, lower monopsonistic power. Stronger local labor market competition associated to higher density can also favor poaching, thereby reducing retention probabilities for any wage 
differential. Closely related to poaching and to better matching opportunities is the fact that labor turnover is higher in denser areas, which gives firms located in these areas better opportunities to hire skilled workers from the market and reduces the incentive to train (Brunello and Medio [2001]). In our stylized model, the measure of labor market competition is $k=\frac{\Phi(0)}{\phi(0)}=\frac{1}{2 \phi(0)}$. Denser and more competitive labor markets have a higher value of $\phi(0)$. Therefore $\frac{\partial k}{\partial D}<0$. Figure 3 shows two standard normal density functions corresponding to two local labor markets. The labor market associated to $\phi_{1}(0)$ is denser than the labor market associated to $\phi_{0}(0)$. Assume that each local market is populated by two (identical) firms. When the wage paid by firm $2, w_{2}$, increases marginally above the wage paid by firm $1, w_{1}$, the marginal reduction in the retention probability $\Phi\left(w_{1}-w_{2}\right)$ is higher in the denser area, because the distribution $\phi$ is more concentrated about the zero mean.

To summarize, the marginal effect of higher density on employer provided training is

$$
\frac{\partial N}{\partial D}=\frac{1}{C^{\prime \prime}}\left[\alpha \frac{\partial v}{\partial D}+\frac{1}{2} \frac{\partial k}{\partial D}+v \frac{\partial \alpha}{\partial D}-\frac{\partial C^{\prime}}{\partial D}\right]
$$

where the double prime is for the second derivative of $C$ with respect to $N^{3}$. The first term within brackets is positive because of the positive product and labor market externalities; the second term is negative because a higher density reduces stickiness, increases labor turnover and reduces as a consequence the monopsonistic power of firms in the local labor market; the third term is positive if better outside opportunities increases the price paid by employees to obtain a training slot; finally, the last term has an uncertain sign, because of the opposing effects of a better labor pool and of higher opportunity costs of training. Overall, the impact of local density on training is uncertain, and depends on the balance of positive and ne gative effects.

This impact is affected by the structure of the local market. In general we expect that the negative poaching effects are stronger in areas with a higher share of small and medium firms. The reason is that smaller firms "..may have higher training costs per employee than larger firms because they cannot spread the fixed costs of training over a large group of employees..." (Lynch, 2003). For these firms, poaching is relatively more attractive. A counter argument is that small and medium firms often belong to informal networks such as industrial districts, where cooperative

${ }^{3} C^{\prime \prime}>0$ because of the convexity of the cost function. 
behavior prevails over competition for skilled labor. Poaching should be smaller in these clusters. We can test whether the share of small and medium firms in a local labor market matters by interacting this variable in the training equation with measures of labor market density.

Equally dense areas which differ in the degree of industrial specialization can exhibit substantially different pooling and poaching effects. On the one hand, specialization can foster network externalities, as in the MAR concept introduced in Section 1 of the paper, and therefore increase beneficial pooling effects. On the other hand, a more specialized industrial structure, with a higher proportion of firms producing closely related products and using closely related processes, can favor within - industry mobility of trained employees, with a negative impact on training, especially if skills are industry specific (see Neal [1995]).

\section{The Econometric Specification}

The model in the previous section suggests that the relationship between employer provided training and the density and specialization of economic activity in local labor markets is complex and cannot be signed a priori. In each area, positive pooling externalities interact with poaching externalities and labor turnover and affect the marginal costs and the marginal benefits of training. The overall effect of density and specialization on employer provided training depends on the relative strength of these forces at play.

Our empirical specification assumes that the individual probability of receiving employer provided training depends on individual, area - specific and aggregate effects. More in detail, we use the following probit specification

$$
\operatorname{Pr} o b\left\{T_{i j t}=1\right\}=\Phi\left\{\beta X_{i j t}+\gamma D_{j t}+\delta Z_{t}+u_{i}+\varepsilon_{i j t}\right\}
$$

where $\mathrm{T}$ is employer - provided training, $\mathrm{X}$ a vector of individual effects, which include age, gender, firm size, education, affiliation to industry and occupation and marital status, D is log employment density, measured as the log of the ratio between employment in the area and the size of the area in squared kilometers, $\mathrm{Z}$ a vector of aggregate time effects, e is a normally distributed and serially uncorrelated error term, $u_{i}$ is a normally distributed and time invariant individual effect, and the indices $i, j$ and $t$ are for the individual, the area and time respectively.

When the data are longitudinal and we estimate the probit model on the pooled cross section and time series data, the failure to account for unobserved heterogeneity - assumed to be orthogonal to the explanatory variables - leads to attenuation bias (Yatchew and Griliches, 1985). If 
our interest is in the average partial effects, defined as the average marginal effects across the distribution of $u$ in the population, this estimation method is consistent. If we are interested instead in the marginal effects, we have to use a random effects estimator (Wooldridge [2002]).

A potentially serious problem with [12] is that the error term can include omitted unobserved area effects, which influence both the probability of training and local employment density, because of endogenous migration. Since local areas with higher unobserved productivity attract people with higher unobserved ability, local employment density and average ability are positively correlated (Glaeser - Marè [2000]). Yatchew and Griliches, [1985], discuss omitted variables bias in the context of the probit model and show that this bias exists even if the omitted variable - in our case unobserved ability or productivity - is uncorrelated with included variables. One natural way to control for omitted area - specific variables is to add to [12] area - specific dummies. If we do so, however, we capture the bulk of agglomeration effects as well, because the time span of our data is not long enough to allow log density to vary significantly over time.

Our strategy i instead to add to the right hand side of [12] the percentage of individuals with a college degree in each local labor market, which should capture an important component of unobserved average ability, because of the well-known correlation between ability and educational attainment (Card [1999]). The training policy of firms can also be affected by local labor market policy. If employer - provided and publicly - provided training are substitutes, we expect the former to be lower, ceteris paribus, in areas where public provision is more widespread. We capture public policy effects with the two dummies $O b 1$ and $O b 2$, which indicate the regions covered by European structural funds under the Objective 1 and Objective 2 programs, and with the local unemployment rate, because public training programs often focus on the unemployed.

We also add the following area - specific variables: average firm size in the manufacturing sector $M$ and an area - specific index of industrial specialization $S$, computed as

$$
S_{j t}=\Sigma_{k}\left(\frac{E_{k j t}}{E_{j t}}\right)^{2}
$$

where $k$ is for the industry in the area ${ }^{4}$ and $E$ is employment, which varies over time and across local labor markets. Finally we add Nuts 1 dummies, which capture all unobserved productivity effects taking place in a group of Nuts 2 local areas but leave enough cross section variation for the eventual identification of a significant relationship between local density and training ${ }^{5}$.

\footnotetext{
${ }^{4}$ Cingano and Schivardi, 2003, use a similar variable.

${ }^{5}$ One of the Nuts 1 dummies is for the Greater London area.
} 
We supplement these estimates by testing the weak exogeneity of employment density in [12] with the Blundell - Smith test (Blundell and Smith [1986]). This test consists of two steps: in the first step local density $D$ is regressed on the full set of exogenous variables as well as on additional instruments; in the second step the residuals from this regressions are included as an additional variable in the probit model. Under the assumptions of normality, the test of weak exogeneity is equivalent to a t-test on the residuals. Given that the area - specific variables used in [12] are at a higher level of aggregation than individual information on employer - provided training, the errors are likely to be correlated within clusters but independent between clusters. We correct the standard errors of the estimates for the presence of area, industry and time clus ter effects in the error term, depending on the selected specification.

Since abler individuals are more likely to live in denser areas, an alternative approach is to estimate a linear probability version of [12] by using a fixed effects estimator. The trouble with this approach, however, is that it removes not only individual fixed effects but also all area - specific variables which exhibit limited time variation. Therefore, we follow Black and Lynch [2001] and first estimate

$$
T_{i j t}=\theta X_{i j t}+\sigma Z_{t}+\lambda R D_{j}+v_{i}+\mu_{i j t}
$$

where $R D$ is Nuts 2 dummies, using the fixed effects estimator. Next, we compute the residuals $T_{i j t}-\hat{\theta} X_{i j t}$ and average them over areas and time to obtain $R_{j t}$, the dependent variable in the second stage regression

$$
R_{j t}=\phi D_{j t}+\kappa Z_{t}+\varsigma Y_{j t}+\eta_{j t}
$$

where $Y$ includes the area - specific controls discussed above. The advantage of this procedure is that it controls in the first stage for individual unobserved heterogeneity.

Since we expect that the relationship between local employment density and employer provided training vary with the structure of local industry, we interact employment density in [12] with average firm size in the area. In the literature on local agglomeration effects and on the economics of cities, much emphasis has been placed on the concepts of MAR and Jacobs externalities. As discussed in the review of the literature, these concepts capture within - area industry specific agglomeration effects. The former is an industry - specific index of industrial specialization, computed as (see Combes [2001]) 


$$
M A R_{k j t}=\frac{E_{k j t}}{E_{j t}}
$$

and the latter an industry - specific index of industrial diversity, computed as

$$
J_{k j t}=1 /\left(\Sigma_{\gamma \neq k}\left[\frac{E_{\gamma j t}}{E_{j t}}\right]^{2}\right)
$$

Compared to the index $S$, which varies by region, indices $M A R$ and $J$ vary both by region and by industry. We test whether these indices affect employer - provided training by estimating the following version of [12]

$$
\operatorname{Pr} o b\left\{T_{i j t}=1\right\}=\Phi\left\{\beta X_{i j t}+\gamma R D_{j}+\delta Z_{t}+\theta W_{i k t}+\varepsilon_{i j t}\right\}
$$

where $W$ is a vector which includes MAR and Jacobs externalities. In this specification we exploit the fact that the indicators in $W$ vary by region, time and industry and control for unobserved area effects with Nuts 2 dummies.

\section{The Data}

Our source of data is the December 2001 release of the European Community Household Panel (ECHP), a longitudinal household and personal survey modeled on the US Panel Study of Income Dynamics (PSID). The British data in the ECHP are a sub - sample of the British Household Panel Survey. For each individual, the survey gives information on employer - provided training and on the area of residence of the household. This area, however, does not necessarily coincide with the area of employment, to which the concept of employment density discussed in the paper applies.

The lack of coincidence between area of residence and area of work is a serious problem when we select relatively fine definitions of areas of residence, such as Nuts 3 or higher ${ }^{6}$, because these regions do not necessarily correspond to the travel to work areas (TTWA) defined by commuting behavior. The mismatch between residence and work is less serious, however, when the areas of residence are broader, as in the case of Nuts 2 and Nuts 1 . The natural choice in our context

\footnotetext{
${ }^{6}$ Regional areas in the European Communities are organized into Nuts levels, depending on the degree of aggregation. For the UK, Nuts 1 regions correspond to Standard Regions, Nuts 2 areas to Groups of Counties, and Nuts 3 areas to Counties.
} 
is the Nuts 2 aggregation (Groups of Counties). In the UK the average size of a group of counties is 6914 square kilometers, wide enough to have most residents working in the area. Broader or finer classifications such as Nuts 1 and Nuts 3 would be less appropriate, either because pooling externalities dissipate over larger regions (see Ciccone [2001]) or because the areas are too small to contain the relevant TTWA. An attractive feature of ECHP data is that the information on the region of residence for the UK is provided at the Nuts 2 level ${ }^{7}$.

Figure 4 shows a map of Britain divided into Nuts 2 areas. Even by choosing the Nuts 2 classification, however, we cannot completely rule out that, for some individuals in the sample, area of residence and area of work do not cincide. Therefore our empirical indicator of density measures true density with error. Under the conditions spelled out by Yatchew and Griliches ${ }^{8}$, [1985], measurement error generates an attenuation bias in the estimated relationship between the probability of training and local density. We try to attenuate the measurement error associated to the mismatch between area of birth and area of residence by experimenting with an alternative measure of density, the average density of the region of residence and of the neighboring regions.

The main question on vocational training in the ECHP is as follows "Have you at any time since January (in the previous year) been in any vocational education or training, including parttime and short-courses?". Since the reference period may overlap with the reference period of the previous wave, long training events could be counted more than once. According to Arulampalam et al [2003], however, there is little chance of double counting in Britain, because training events are generally very short. Conditional on a positive answer to the training question, the individual is asked whether training was paid for or organized by the employer. If more than one concurrent course are involved, only information concerning the course considered by the respondent as the most important is reported. We do not try to distinguish between general and firm - specific training, mainly because a substantial part of the training reported in the ECHP is general in nature (see Bassanini and Brunello [2003]). We define $T=1$ if the individual has received any vocational education or training since January of the year before the survey, and $T=0$ otherwise.

Our sample comprises men and women who are (i) between the ages of 17 and 59 years working at least 15 hours per week; (ii) not employed in agriculture, the public sector or non-profit organizations. We pool all observations from the first (1994) to the last available wave (2000) and use time dummies to account both for aggregate effects and for the fact that the training question has been somewhat altered from 1998 onwards (see Arulampalam et al. [2003]).

\footnotetext{
${ }^{7}$ Regional information in the BHPS is either at the Nuts 3 level, but only in the last three waves, or at a finer level of disaggregation. Personal communication with John Brice of Essex University suggests that the aggregation of the original data at the Nuts 2 level would require a lot of geographical knowledge or reference data.

${ }^{8}$ The key condition is that the measurement error is normally distributed.
} 
Our measure of density is total employment in private industry and services per squared kilometer. Total employment in private industry and services in each Nuts 2 area and for each year is computed as follows: a) we obtain aggregate employment from official Eurostat publications; b) we use the cross-sectional ECHP stratification weights to compute for each available year the distribution of employment by local area and disaggregate aggregate data by Nuts 2 area ${ }^{9}$. Regional Nuts 2 variables such as the unemployment rate and average firm size in manufacturing are computed using the ISY Databank ${ }^{10}$ and the online information from the website www.nomisweb.co.uk.

Table 1 presents for the year 1997 the descriptive statistics of the main variables used in the empirical analysis. On average about $30 \%$ of the individuals in the sample has been involved in employer provided training, a number which is broadly in line with official statistics (see OECD [2003]). Close to $50 \%$ of the sampled individuals have at least upper secondary education, and a similar percentage applies to employees in medium and large firms and to marital status. Average total employment in the Nuts 2 areas was 608.3 thousand employees in 1997, with a minimum of 148.2 thousand (North Yorkshire) and a maximum of 1574 thousand (Greater London). Average employment density was 209 employees per squared kilometer, ranging between 12 in South Western Scotland and 982 in Greater London, and average firm size in manufacturing was 25.86, with a range between 12.67 and 39.29. The unemployment rate in 1997 was on average 0.066, with a minimum of 0.03 (Oxfordshire) and a maximum of 0.129 (Merseyside), and the percentage of college graduates in each group of counties were on average 0.229 , with a range between 0.091 and 0.325. Finally, the index of industrial specialization (MAR) in the same year was on average 0.139, with a range between 0.017 and 0.320 , and the index of industrial diversity was on average equal to 7.320 , with a minimum of 3.580 and a maximum of 17.184 .

\section{The Results}

We start the presentation of our results with Tables 2, which shows the estimates of the probit model [12] on the pooled sample. The numbers in the table are not the marginal effects, but the average partial effects of a unit change in each explanatory variable. The difference between these two measures can be illustrated as follows: et $\operatorname{Pr} o b\{y=1 \mid x\}=\Phi(x \beta)$ be the probit model. The marginal effect of a unit change in $x_{j}$ is $\beta_{j} \phi(\bar{x} \beta)$, with the density evaluated at the mean value

\footnotetext{
${ }^{9}$ An alternative to a) is to use Nuts 1 employment (source: www.nomisweb.co.uk) and disaggregate it by Nuts 2 area using b). Results are very close to the ones obtained with the methodology described in the text.

${ }^{10}$ Available at the Department of Economics, University of Padova
} 
of $\mathrm{x}, \bar{x}$. In the presence of neglected heterogeneity $u \approx N\left(0, \tau^{2}\right)$, the probit model in latent variable form is $y^{*}=x \beta+\gamma u+\varepsilon$ and $\operatorname{Pr} o b\{y=1 \mid x\}=\Phi\left(\frac{x \beta}{\sigma}\right)$, where $\sigma^{2}=\gamma^{2} \tau^{2}+1$. The average partial effect is $\frac{\beta}{\sigma} \phi\left(\frac{\bar{x} \beta}{\sigma}\right)$, which corresponds to the average marginal effect across the distribution of $u$ in the population (Wooldridge, 2002).

Table 2 is organized in six columns. We start from the most parsimonious specification in column 1 and add progressively the percentage of college graduates in the area, the local unemployment rate, the index of specialization, the log average firm size and the interaction of firm size with employment density. We find that individual controls attract the expected sign - negative for age, positive for male employees and for the workers in medium and large firms. The estimated effect of log employment density on employer - provided training is negative and statistically significant in all specifications. Training is higher in Nuts 2 areas with higher average firm size and a higher share of college graduates, and lower in Nuts 2 areas with higher unemployment rate and area - specific industrial specialization.

The interaction of $\log$ density with average firm size has a positive and statistically significant coefficient. Therefore, the negative correlation between employment density and employer - provided training is lower the higher the average firm size in the area. A natural interpretation this result is that labor turnover is higher in areas where small firms prevail, which encourages these firms to hire the required skills from the market as an alternative to costly training ${ }^{11}$. When evaluated at the sample mean value of log firm size (3.208), the average partial effect of a 10 percent change of employment density on the probability of employer - provided training is equal to $-.07[(-.113+.033 * 3.208) * 10]$.

We formally assess whether log employment density is weakly exogenous by applying to our model the Blundell-Smith [1986] test. This test consists of two steps: in the former step we regress log employment density on the set of instruments, which includes all the explanatory variables in [12] plus the log of the size of each Nuts 2 area, measured in squared kilometers, as the additional instrument. As discussed by Ciccone [2001], since the borders of Nuts 2 areas are set by administrative reasons, the size of the local area is a valid instrument, because it is correlated with density by construction but not correlated with employer - provided training, conditional on density. In the second step we add to the right hand side of [12] the residuals from the first step regression and test whether they are significantly different from zero. Table 3 shows the results for the most and the least parsimonious specification in Table 2. Our evidence is that the residuals are not

\footnotetext{
${ }^{11}$ The correlation between the average firm size in manufacturing and annual labor turnover in 1991 in Nuts 1 areas was 0.784 .
} 
statistically different from zero, which leads us to reject the hypothesis of no weak exogeneity of employment density.

Next we turn to the linear probability model [14]-[15] and present in Table 4 the results of the second stage regression [15]. We find that the impact of log employment density on employerprovided training, net of individual effects, is negative, statistically significant and of the same order of magnitude of the impact found in Table 2. Additional evidence in favor of a negative correlation between local density and training comes from the random effects probit ${ }^{12}$ estimates in Table 5.

This result contrasts with the positive correlation between local employment density and value added productivity found by Ciccone and Hall, 1996, and Ciccone, 2002, and suggests that the productivity gains associated to denser economic activity are not due to the fact that firms in denser areas train more their employees. Ceteris paribus, firms in denser areas train less than firms in other areas. We interpret this as evidence that the positive pooling externalities which favor training in denser areas are more than offset by the negative poaching and turnover effects.

This interpretation requires that turnover and poaching are higher in denser areas. One piece of evidence that labor mobility is higher in denser areas is that the correlation between labor turnover, as measured in the 1991 Employer's Manpower and Skill Practices Survey (see Martin [1993]), and log employment density in British Nuts 1 areas is positive and equal to 0.49. Other evidence is that the correlation between the percentage of unfilled skilled vacancies on total local employment and log employment density in Nuts 1 areas is negative and equal to $-0.66^{13}$. The fact that denser areas have relatively fewer unfilled skilled vacancies as a percentage of local employment suggests that firms in these areas have less pressure to train employees because of the difficulties encountered in hiring the required skills from the market.

If poaching is higher in denser areas, we should find that in these areas employer - provided training has a positive effect on voluntary mobility. The ECHP dataset provides information on whether an individual has changed job in the reference period, defined as the year of the interview or the year immediately before, to obtain a better or more suitable job. We estimate a probit model, which associates the probability of turnover to individual characteristics, individual tenure and employer - provided training in the year before the reference period. In the estimates reported in Table 6 we define the dummy "high density" as equal to one if the local area has density higher or equal to median density and to zero otherwise, and interact this dummy with previous training. We

\footnotetext{
${ }^{12}$ The coefficients reported in the table are the estimates of $\beta$ and $\sigma$ in the model $\operatorname{Pr} o b\{y=1 \mid x\}=\Phi\left(\frac{x \beta}{\sigma}\right)$.

${ }^{13}$ The data on unfilled vacancies by occupation are from the website www.nomisweb.co.uk. We classify as skilled the vacancies for managers, professional, technicians and craft workers.
} 
find that the impact of previous training on turnover is not significantly different from zero, but that the coefficient associated to the interaction term is both statistically significant and positive. We interpret this as evidence that the effect of employer - provided training on voluntary turnover is positive in denser areas, which are more exposed to negative poaching effects.

The uncovered negative relationship between density and employer - provided training could be explained if this type of training and the training provided by the employee or by the local government are substitutes and the latter type of training is more frequent in denser areas. To check this, we have computed for each area and year the percentage of trained individuals - employed or not - who have been involved in training that was not employer - provided, and added this variable to the right hand side of [12]. It turns out that the estimated coefficient associated to this variable is positive but not statistically significant, which does not support the hypothesis of substitutability between different types of training ${ }^{14}$.

The random effects estimates in Table 5 also confirm the negative relationship between employer provided training and the area - specific index of industrial specialization found in Table 2: conditional on employment density, the higher concentration of local employment in a few sectors reduces employer - provided training. We further investigate the relationship between industrial specialization and training by using two industry and area - specific variables: $M A R$, the percentage of employees in the industry and area over total employment in the area, and $J$, the industry and area - specific measure of industrial diversity. Since both indicators vary by area and industry, we control for area - specific effects - such as employment density - by using Nuts 2 area dummies. Table 7 shows that employer - provided training is significantly lower when industrial specialization is higher, which confirms our previous results. Conditional on specialization, we also find a positive but not statistically significant impact of industrial diversity. As discussed in Section 2 of the paper, industrial specialization can affect both the positive local pooling effects and the negative poaching and turnover effects. Our results suggest that the negative poaching and turnover effects are stronger and/or the pooling effects weaker when the local industrial structure is more specialized.

\section{Robustness}

In this section we investigate the robustness of our results to changes in sample size and in the definition of employment density. We start in Table 8 by replicating our estimates of the least parsimonious model in Table 2 on the sub-sample covering the years 1994-97 (column (1) in the table), on the sub-sample of individuals aged 25 to 59 (column (2)) and by adding to the regressors

\footnotetext{
${ }^{14}$ Results available on request.
} 
in [12] the lagged dependent variable. In the last column of the table we show the estimates of the baseline model when the dependent variable extends to all training events, including those not explicitly paid for or organized by the employer.

We exclude the years 1998-2000 in the first exercise because of a change in the wording of the question on training in the ECHP after 1997; we remove individuals aged between 17 and 24 because the training of this group is likely to include both initial vocational training as well as continuing training, which is typical of the older age group (see Arulampalam et al [2003]). We add the lagged dependent variable to take into account the time persistency of training. Finally, we experiment with all training events because it might be difficult for the interviewed individual to distinguish in a meaningful way between employer - provided and other types of training, as discussed in some detail by Bassanini and Brunello [2003]. The results in Table 8 show that the relationship between training and log employment density is robust to changes in the sample and in the definition of the dependent variable.

Next we experiment with alternative definitions of log employment density, our key explanatory variable. We have computed employment in the private non - agricultural sector at the Nuts 2 level by using the ECHP distribution of employment by local area to disaggregate private non - agricultural national employment. An alternative procedure is to use these weights to disaggregate Nuts 1 employment. The first column in Table 9 replicates the estimates of the least parsimonious model in Table 2 when we use this alternative procedure, with no qualitative change of results. The measure of density used in the paper does not distinguish between skilled and unskilled employment, in line with the existing literature. One could argue, however, that the source of pooling externalities as well as of poaching effects is skilled rather than total employment. In the second column of Table 9 we restrict our measure of local density to skilled employment, which we identify with the following occupations: managers, professionals, technicians and craft workers. We find that the relationship between density and employer - provided training is robust to these changes in the definition of density.

We have identified local labor markets with groups of counties, the Nuts 2 classification of regional areas, because this classification is wide enough to contain most relevant travel to work areas but not too large to determine the dissipation of pooling externalities. One potential problem here is that individuals who reside near the border of a group of counties could be employed across the border, in another group of counties. Furthermore, as argued by Ciccone [2001], there is no strong reason to believe that spatial externalities do not involve neighboring regions.

We deal with these problems as follows. First, we replace density in each Nuts 2 area of residence with the average of this density and the density of neighboring regions, which share their borders with the area. By so doing, we are able to minimize the impact of any mismatch between 
area of residence and area of work, which remains after choosing a reasonably wide reference area, the group of counties. The results in the first column of Table 10 suggest that the negative relationship between employer - provided training and density is robust. Second, we augment the least parsimonious specification in Table 2 with an additional measure of density, the average employment density of neighboring areas, obtained by averaging the densities of the areas which share borders with each Nuts 2 region. The results in the second column of Table 10 show that both measures of density attract a negative and statistically significant coefficient. We find this result reassuring, because the negative correlation between employer - provided training and employment density is not affected by eventual misallocations of individuals to the relevant region of employment.

\section{Conclusions}

The key finding of this paper is that employer - provided training is less frequent in economically denser areas. We have explained this outcome as the result of the interaction between the positive pooling effects and the negative poaching and turnover effects of agglomeration. The size of the negative effect is not negligible: when evaluated at the average firm size in the area, a 10 percent increase in density reduces the probability of employer - provided training by 0.07 , more than 20 percent of the average incidence of training in the UK during the sample period.

In a well-known paper, Hall and Ciccone, [1996], find that higher density increases average productivity in the area by 5 percent. Our results suggest that this effect could have been even higher were it not for the negative impact of density on employer - provided training. Higher density affects productivity both directly, by facilitating the creation and diffusion of innovation, and indirectly, by affecting the composition of labor in the local area. Denser areas attract individuals with higher education, who are more productive and learn new skills faster. Faster learning encourages training. The same areas, however, are characterized by higher labor mobility, which reduces the incentive of firms to train. Overall, productivity can be higher in denser areas despite the fact that employer - provided training is lower.

Public policy needs to establish whether the level of privately provided training is too low (or too high). This is not an easy task. If policy aims more simply at increasing the stock of human capital in local labor markets, our empirical findings for the UK suggest that public intervention should not disregard denser, and possibly thriving, economic areas, because the inner incentive of firms to train in these areas may be lower than elsewhere. 


\section{References}

Acemoglu, D. and Pischke, J. [1999], The structure of wages and investment in general training, Journal of Political Economy, 107, 539-572

Acemoglu, D., [2000], Technical Change, Inequality and the Labor Market, NBER Working Paper \#7800

Almazan, A, de Motta, A and Titman, S. [2003], Firm location and the creation and utilization of human capital, NBER Working Paper \# 10106.

Arulampalam, W., Booth, A. and Bryan, M., [2003], Training in Europe, mimeo, Essex University.

Audretsch, D.B., Feldman, M.P.,[2004], Knowledge spillovers and the goegraphy of innovation, in Thisse, J_F., Henderson, J.V. (eds), Handbook of Urban and Regional Economics, fortcoming.

Black, S. and Lynch, L., [2001], How to compete: the impact of workplace practices and information technology on productivity, The Review of Economics and Statistics, 83(3): 434-45

Booth, A., Francesconi, M. and G. Zoega [1999], Training, rent sharing and unions, mimeo, Essex University.

Bassanini, A. and Brunello, G., [2003], Is training more frequent when wage compression is higher? Evidence from the European Community Household Panel, IZA Discussion Paper 839

Becker, G. [1964], Human Capital, The University of Chicago Press, Chicago.

Brunello, G. and Medio, A., [2001], An explanation of international differences in education and workplace training, The European Economic Review, pp.307-322

Card, D., [1999], The causal effect of education on earnings, in Ashenfelter, O. and Card, D., Handbook of Labor Economics, North Holland, Volume 3A 
Ciccone, A. and Hall, R., [1996], Productivity and the density of economic activity, American Economic Review, pp.54-70.

Ciccone, A., [2002], Agglomeration effects in Europe, The European Economic Review, pp.213227.

Cingano, F. and Schivardi, F., [2003], Identifying the sources of local productivity growth, Bank of Italy, mimeo.

Combes, P. and G. Duranton, [2001], Labor pooling, labor poaching and spatial clustering, LSE Discussion Paper 2975.

Combes, P. [2000], The economic structure and local growth: France 1984-93, Journal of Urban Economics, 47(3): 329-55.

Glaeser, E., Kallal, H., Scheinkman, J. and Shleifer, A., [1992], Growth in Cities, Journal of Political Economy, 100, 1126-52,

Glaeser, E. and Mare, D., [2000], Cities and Skills, Journal of Labor Economics, pp:124-157

Henderson, V., Kuncoro, A., Tuner, M., [1995], Industrial development in Cities, The Journal of Political Economy, 103(5), 1067-1090.

Krugman, P., [1991], Geography and Trade, MIT Press.

Lynch, L., [2003], Development intermediaries and the training of low wage workers, mimeo, Tufts University.

Martin, C., [1993], Labor Turnover: evidence from UK establishments, Brunel University, mimeo

Neal, D., [1995], Industry-Specific Human Capital: Evidence from Displaced Workers Journatof-Labor-Economics, 13(4): 653-77

Rosenthal, S. and Strange, W., [2003], Geography, industrial organization and agglomeration, The Review of Economics and Statistics, 85, 2, 377-393 
Rosenthal, S. and Strange, W., [2004], Evidence on the nature and sources of agglomeration economies, in Thisse, J_F., Henderson, J.V. (eds), Handbook of Urban and Regional Economics, forthcoming.

Stevens, M. [1995], Transferable training and poaching externalities, in Booth and Snower, Acquiring skills, Cambridge University Press, Cambridge, pp. 19-40.

Yatchew, A. and Griliches, Z., 1985, Specification errors in probit models, Review of Economics and Statistics, 67, 1, 134-139

Zenou, Y., [2003], Urban labour economic theory, CEPR Discussion Paper 4029, London.

Wooldridge, J. [2002], Econometric analysis of cross section and panel data, The MIT Press, Boston. 
Figure 1. Employer provided training by NUTS 2 region, 1997.

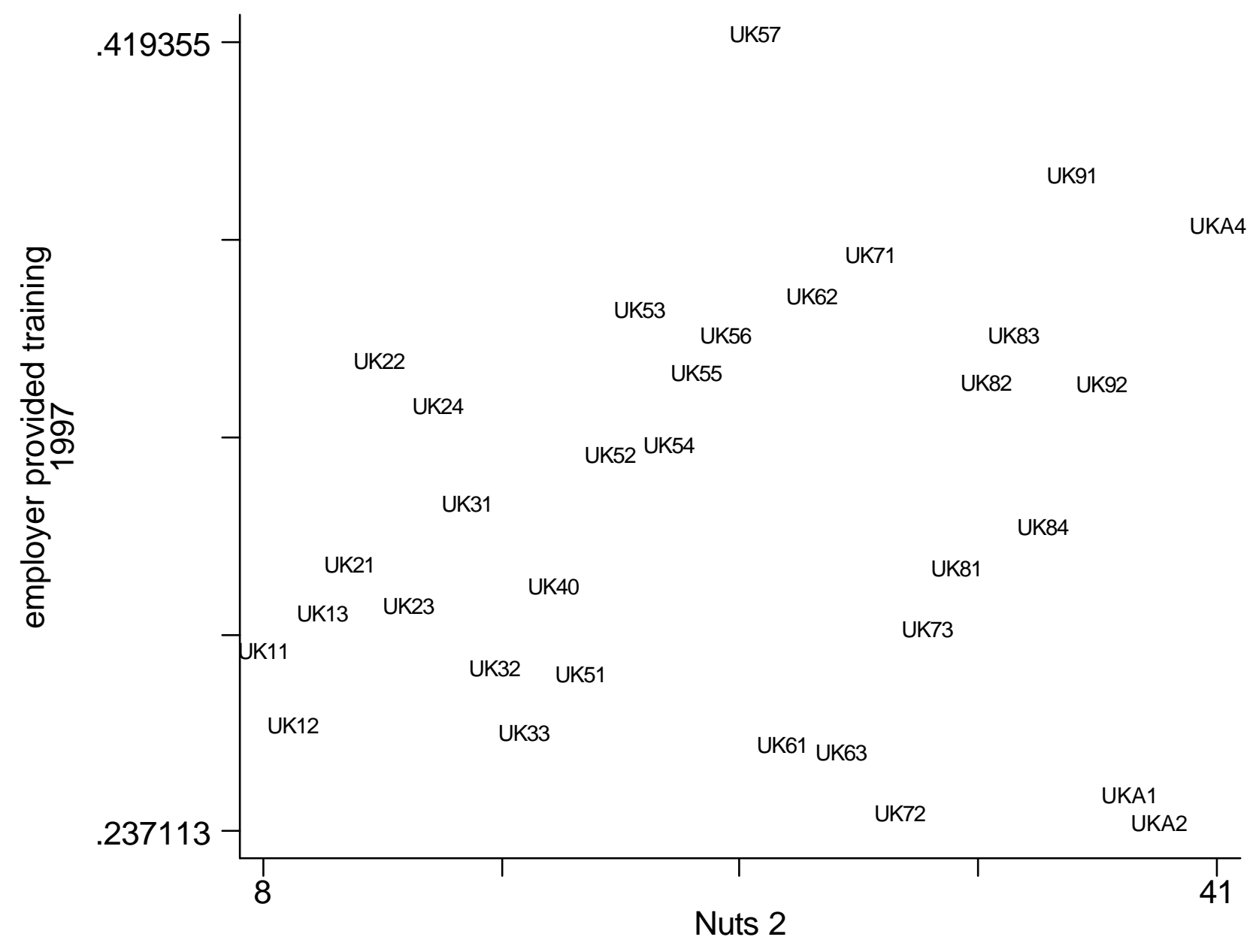


Figure 2. Employer provided training and log employment density, by NUTS 2 regions, 1997.

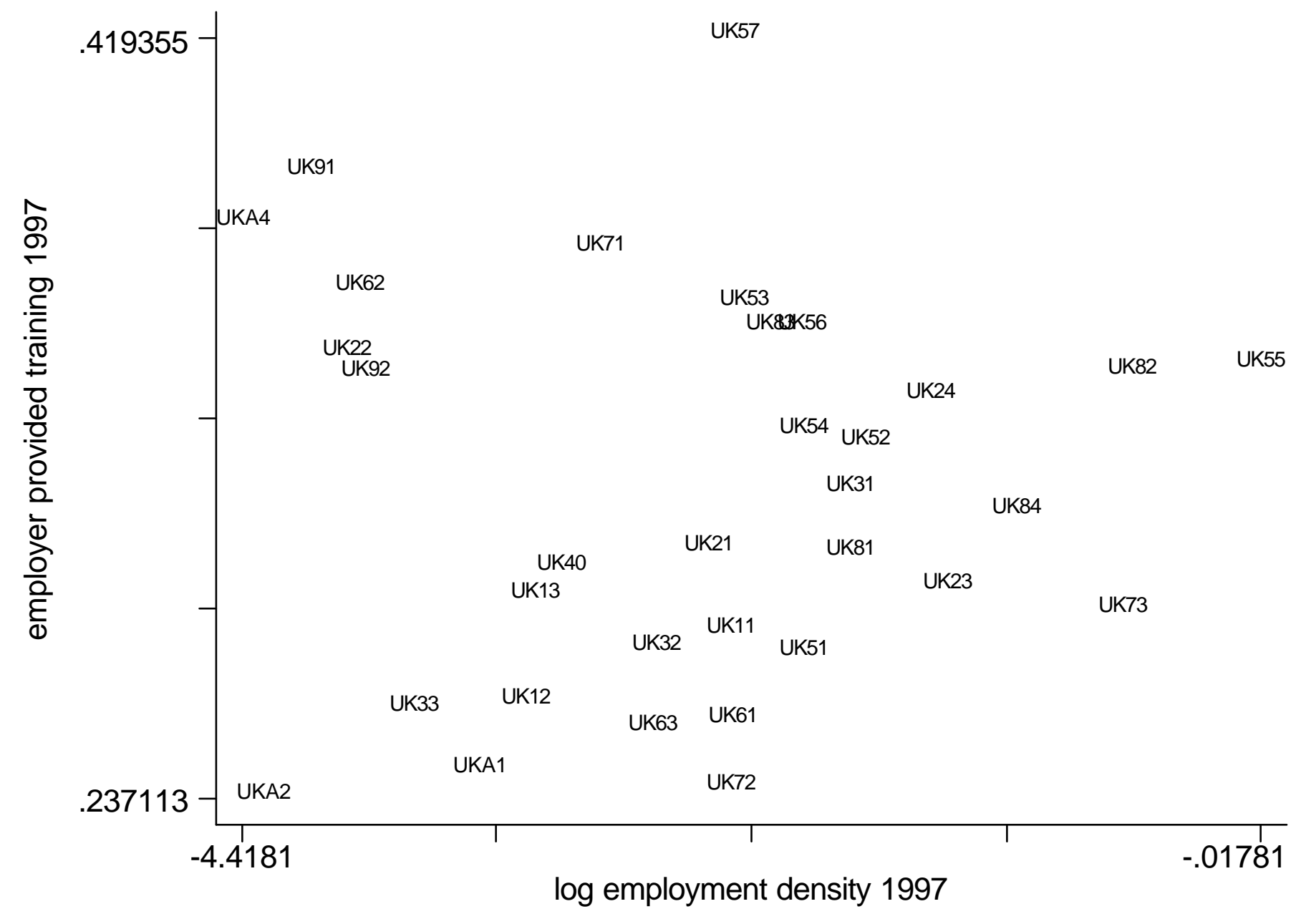


Figure 3. Retention Densities

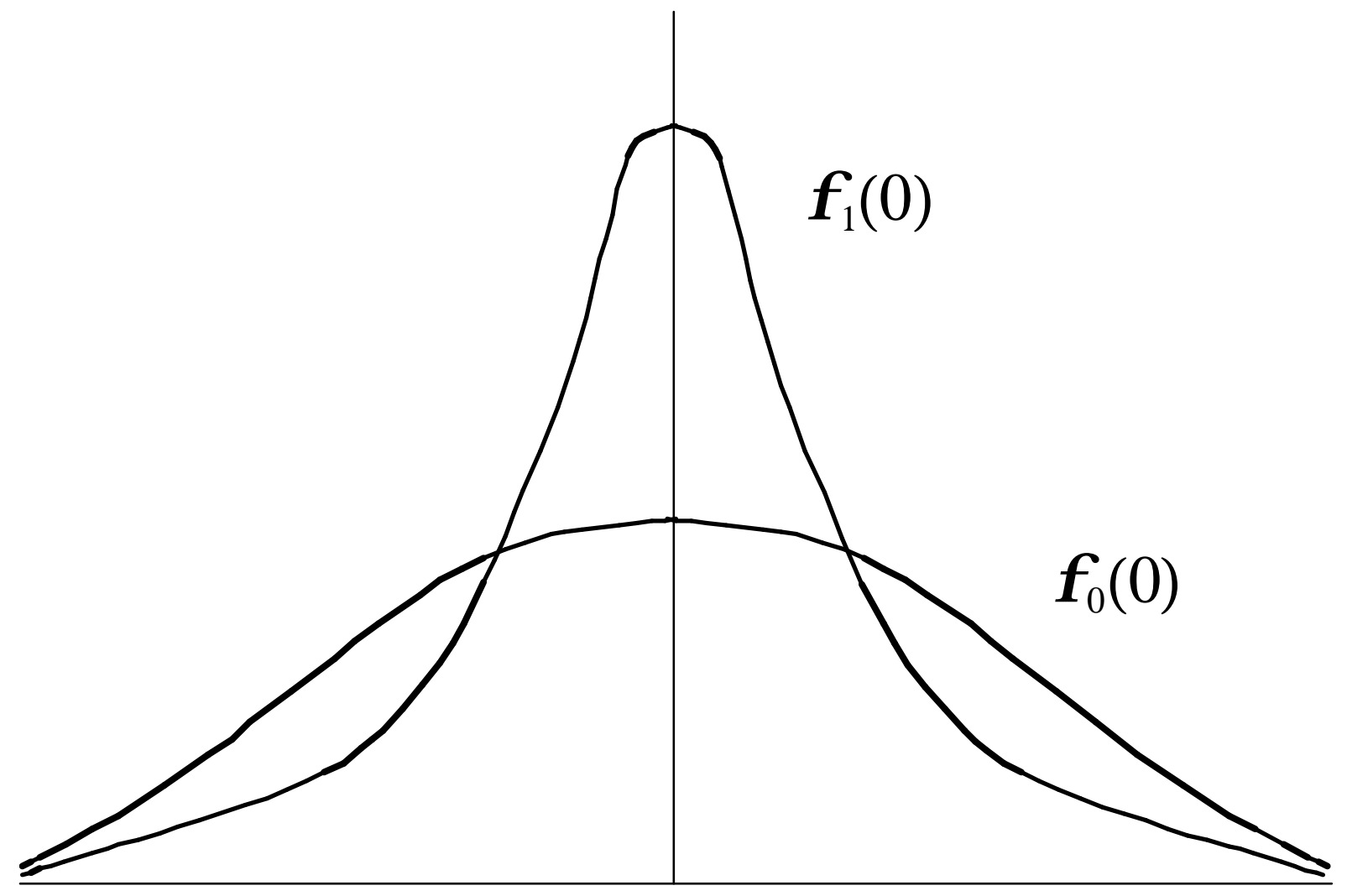


Figure 4. Nuts 2 (Group of counties) map in the UK

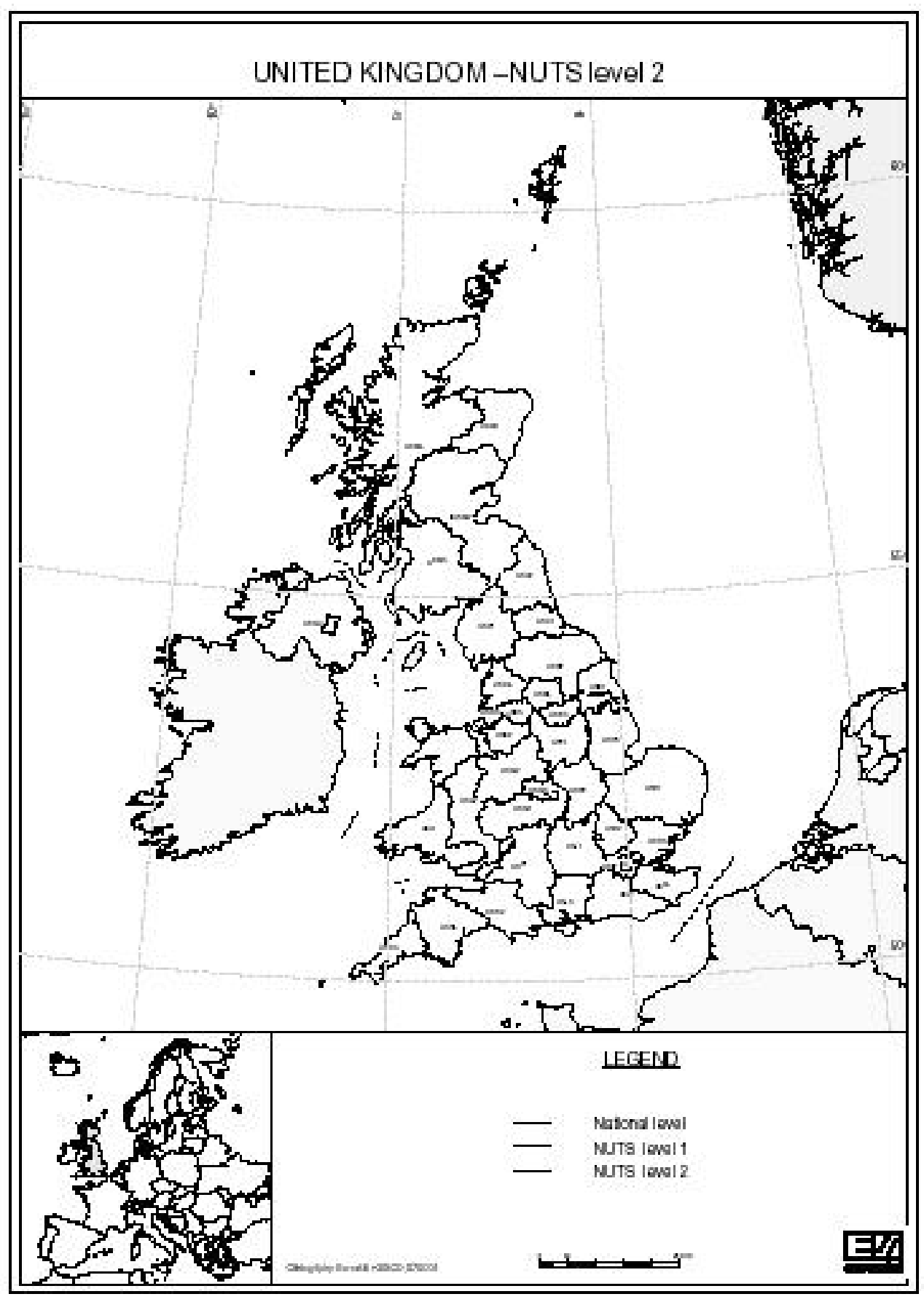


Table 1. Summary Statistics. ECHP 1997

\begin{tabular}{|c|c|c|c|c|}
\hline & Mean & Std. Dvt. & Min & Max \\
\hline Employed provided training & .306 & & & \\
\hline Gender & .589 & & & \\
\hline Married & .522 & & & \\
\hline Medium-sized firm & .111 & & & \\
\hline Large-sized firm & .412 & & & \\
\hline High School and higher & .567 & & & \\
\hline Objective 1 Dummy & .015 & & & \\
\hline Objective 2 Dummy & .255 & & & \\
\hline Age & 35.41 & 10.74 & & \\
\hline $\begin{array}{l}\text { Total employment in the Nuts } 2 \text { area } \\
\text { (thousands) }\end{array}$ & 608.34 & 374.22 & 148.2 & 1574.0 \\
\hline Log firm size in manufacturing & 25.86 & 5.311 & 12.67 & 39.29 \\
\hline Local unemployment rate & .066 & .027 & .030 & .129 \\
\hline $\begin{array}{l}\text { Log employment density in the Nuts } \\
2 \text { area }\end{array}$ & .209 & .284 & .012 & .982 \\
\hline $\begin{array}{l}\text { Percentage of college graduates in } \\
\text { the area }\end{array}$ & .229 & .052 & .091 & .325 \\
\hline $\begin{array}{l}\text { Region specific index of } \\
\text { specialization in the Nuts } 2 \text { area }\end{array}$ & .131 & .020 & .097 & .164 \\
\hline $\begin{array}{l}\text { Industry specific index of MAR } \\
\text { externalities }\end{array}$ & .139 & .077 & .017 & .320 \\
\hline $\begin{array}{l}\text { Industry specific index of Jacobs } \\
\text { externalities }\end{array}$ & 7.320 & 2.780 & 3.580 & 17.184 \\
\hline
\end{tabular}


Table 2. Probit estimates of the probability of employer - provided training. Pooled cross section time series data. Average partial effects. Dependent variable: T

\begin{tabular}{|c|c|c|c|c|c|c|}
\hline & (1) & (2) & (3) & (4) & (5) & (6) \\
\hline Age & $\begin{array}{c}-.008 * * * \\
(.002)\end{array}$ & $\begin{array}{c}-.008 * * * \\
(.002)\end{array}$ & $\begin{array}{c}-.008 * * * \\
(.002)\end{array}$ & $\begin{array}{c}-.008 * * * \\
(.002)\end{array}$ & $\begin{array}{c}-.008 * * * \\
(.002)\end{array}$ & $\begin{array}{c}-.008 * * * \\
(.002)\end{array}$ \\
\hline Age squared & $\begin{array}{l}.000 * * * \\
(.000)\end{array}$ & $\begin{array}{l}.000 * * * \\
(.000)\end{array}$ & $\begin{array}{c}.000 * * * \\
(.000)\end{array}$ & $\begin{array}{c}.000 * * * \\
(.000)\end{array}$ & $\begin{array}{c}.000 * * * \\
(.000)\end{array}$ & $\begin{array}{c}.000 * * * \\
(.000)\end{array}$ \\
\hline Gender & $\begin{array}{l}.022 * * * \\
(.007)\end{array}$ & $\begin{array}{l}.022 * * * \\
(.007)\end{array}$ & $\begin{array}{l}.022 * * * \\
(.007)\end{array}$ & $\begin{array}{c}.022 * * * \\
(.007)\end{array}$ & $\begin{array}{c}.022 * * * \\
(.007)\end{array}$ & $\begin{array}{c}.022 * * * \\
(.007)\end{array}$ \\
\hline Medium-sized firm & $\begin{array}{l}.038 * * * \\
(.012)\end{array}$ & $\begin{array}{l}.038 * * * \\
(.012)\end{array}$ & $\begin{array}{c}.038 * * * \\
(.012)\end{array}$ & $\begin{array}{c}.038 * * * \\
(.012)\end{array}$ & $\begin{array}{l}.038 * * * \\
(.012)\end{array}$ & $\begin{array}{c}.038 * * * \\
(.012)\end{array}$ \\
\hline Large-sized firm & $\begin{array}{c}.079 * * * \\
(.007)\end{array}$ & $\begin{array}{l}.079 * * * \\
(.007)\end{array}$ & $\begin{array}{l}.079 * * * \\
(.007)\end{array}$ & $\begin{array}{l}.079 * * * \\
(.007)\end{array}$ & $\begin{array}{l}.079 * * * \\
(.007)\end{array}$ & $\begin{array}{l}.079 * * * \\
(.007)\end{array}$ \\
\hline $\begin{array}{l}\text { High School and } \\
\text { college degree }\end{array}$ & $\begin{array}{c}.065 * * * \\
(.007)\end{array}$ & $\begin{array}{c}.065 * * * \\
(.007)\end{array}$ & $\begin{array}{c}.065 * * * \\
(.007)\end{array}$ & $\begin{array}{c}.065 * * * \\
(.007)\end{array}$ & $\begin{array}{c}.065 * * * \\
(.007)\end{array}$ & $\begin{array}{c}.065 * * * \\
(.007)\end{array}$ \\
\hline Married & $\begin{array}{c}.036 * * * \\
(.007)\end{array}$ & $\begin{array}{c}.036 * * * \\
(.007)\end{array}$ & $\begin{array}{l}.036 * * * \\
(.007)\end{array}$ & $\begin{array}{c}.035 * * * \\
(.006)\end{array}$ & $\begin{array}{c}.035 * * * \\
(.006)\end{array}$ & $\begin{array}{c}.035 * * * \\
(.006)\end{array}$ \\
\hline $\begin{array}{l}\text { Log employment } \\
\text { density in the Nuts } 2 \\
\text { area }\end{array}$ & $\begin{array}{c}-.020 * * * \\
(.004)\end{array}$ & $\begin{array}{c}-.020 * * * \\
(.004)\end{array}$ & $\begin{array}{c}-.013 * * \\
(.006)\end{array}$ & $\begin{array}{c}-.014 * * \\
(.006)\end{array}$ & $\begin{array}{c}-.014 * * \\
(.006)\end{array}$ & $\begin{array}{c}-.113 * * * \\
(.033)\end{array}$ \\
\hline $\begin{array}{l}\text { Percentage of college } \\
\text { graduates in the Nuts } \\
2 \text { area }\end{array}$ & & $\begin{array}{l}.105 \\
(.092)\end{array}$ & $\begin{array}{l}.146 \\
(.092)\end{array}$ & $\begin{array}{l}.168^{*} \\
(.094)\end{array}$ & $\begin{array}{l}.188^{*} \\
(.103)\end{array}$ & $\begin{array}{l}.237 * * \\
(.096)\end{array}$ \\
\hline $\begin{array}{l}\text { Local unemployment } \\
\text { rate }\end{array}$ & & & $\begin{array}{l}-.434 * \\
(.268)\end{array}$ & $\begin{array}{l}-.389 \\
(.264)\end{array}$ & $\begin{array}{l}-.323 \\
(.267)\end{array}$ & $\begin{array}{l}-.324 \\
(.270)\end{array}$ \\
\hline $\begin{array}{l}\text { Area - specific index } \\
\text { of industrial } \\
\text { specialization in the } \\
\text { Nuts } 2 \text { area }\end{array}$ & & & & $\begin{array}{l}-.351 * \\
(.180)\end{array}$ & $\begin{array}{l}-.297 \\
(.193)\end{array}$ & $\begin{array}{l}-.351^{*} \\
(.198)\end{array}$ \\
\hline $\begin{array}{l}\text { Average firm size in } \\
\text { the Nuts } 2 \text { area }\end{array}$ & & & & & $\begin{array}{l}.021 \\
(.023)\end{array}$ & $\begin{array}{c}.067 * * * \\
(.026)\end{array}$ \\
\hline $\begin{array}{l}\text { Average firm size*log } \\
\text { density }\end{array}$ & & & & & & $\begin{array}{c}.033 * * * \\
(.011)\end{array}$ \\
\hline Nuts 1 dummies & Yes & Yes & Yes & Yes & Yes & Yes \\
\hline $\begin{array}{l}\text { Number of } \\
\text { observations }\end{array}$ & 16770 & 16770 & 16770 & 16770 & 16770 & 16770 \\
\hline Pseudo R squared & .114 & .115 & .115 & .115 & .115 & .116 \\
\hline
\end{tabular}

Note: each regression includes a constant, year, industry, occupational dummies and dummies for regions affected by EU Objective 1 and Objective 2 structural funds. Cluster adjusted robust standard errors. One, two and three stars when the coefficients are significantly different from zero at the 10,5 and 1 percent level of confidence respectively. 
Table 3. Probit estimates of the probability of employer - provided training augmented with the residuals from the first step regression of log density on instruments. Pooled cross section time series data. Average partial effects. Dependent variable: $\mathrm{T}$

\begin{tabular}{|c|c|c|}
\hline & (1) & (2) \\
\hline Age & $\begin{array}{c}-.008 * * * \\
(.002)\end{array}$ & $\begin{array}{c}-.008 * * * \\
(.002)\end{array}$ \\
\hline Age squared & $\begin{array}{c}.000 * * * \\
(.000)\end{array}$ & $\begin{array}{c}.000 * * * \\
(.000)\end{array}$ \\
\hline Gender & $\begin{array}{c}.022 * * * \\
(.007)\end{array}$ & $\begin{array}{c}.022 * * * \\
(.007)\end{array}$ \\
\hline Medium-sized firm & $\begin{array}{c}.038^{* * * *} \\
(.012)\end{array}$ & $\begin{array}{c}.038 * * * \\
(.012)\end{array}$ \\
\hline Large-sized firm & $\begin{array}{c}.079 * * * \\
(.007)\end{array}$ & $\begin{array}{c}.079 * * * \\
(.007)\end{array}$ \\
\hline High School and college degree & $\begin{array}{c}.065 * * * \\
(.007)\end{array}$ & $\begin{array}{c}.065^{* * *} \\
(.007)\end{array}$ \\
\hline Married & $\begin{array}{c}.036 * * * \\
(.007)\end{array}$ & $\begin{array}{c}.035 * * * \\
(.006)\end{array}$ \\
\hline $\begin{array}{l}\text { Log employment density in the Nuts } 2 \\
\text { area }\end{array}$ & $\begin{array}{l}-.022 * * * \\
(.004)\end{array}$ & $\begin{array}{c}-.108 * * * \\
(.033)\end{array}$ \\
\hline $\begin{array}{l}\text { Percentage of college graduates in the } \\
\text { Nuts } 2 \text { area }\end{array}$ & & $\begin{array}{l}.239 * * \\
.096)\end{array}$ \\
\hline Local unemployment rate & & $\begin{array}{l}-.362 \\
(.340)\end{array}$ \\
\hline $\begin{array}{l}\text { Area-specific index of industrial } \\
\text { specialization in the Nuts } 2 \text { area }\end{array}$ & & $\begin{array}{l}-.344^{*} \\
(.199)\end{array}$ \\
\hline Average firm size in the Nuts 2 area & & $\begin{array}{l}.066 * * \\
(.026)\end{array}$ \\
\hline Average firm size* $\log$ density & & $\begin{array}{l}.031 * * \\
(.013)\end{array}$ \\
\hline Residuals from first stage & $\begin{array}{l}.004 \\
(.009)\end{array}$ & $\begin{array}{l}-.002 \\
(.014)\end{array}$ \\
\hline Nuts 1 dummies & Yes & Yes \\
\hline Number of observations & 16770 & 16770 \\
\hline Pseudo R squared & .114 & .116 \\
\hline
\end{tabular}

Note: see Table 2. 
Table 4. OLS estimates of the linear probability model, second step [15]. Dependent variable: R

\begin{tabular}{|c|c|c|c|c|c|c|}
\hline & (1) & (2) & (3) & (4) & (5) & (6) \\
\hline $\begin{array}{l}\text { Log employment } \\
\text { density in the Nuts } 2 \\
\text { area }\end{array}$ & $\begin{array}{c}-.017 * * * \\
\quad(.005)\end{array}$ & $\begin{array}{l}-.015 * * * \\
\quad(.005)\end{array}$ & $\begin{array}{l}-.009 \\
(.007)\end{array}$ & $\begin{array}{l}-.012 * \\
(.006)\end{array}$ & $\begin{array}{l}-.012 * \\
(.007)\end{array}$ & $\begin{array}{c}-.128 * * * \\
\quad(.039)\end{array}$ \\
\hline $\begin{array}{l}\text { Percentage of college } \\
\text { graduates in the Nuts } 2 \\
\text { area }\end{array}$ & & $\begin{array}{l}.194 * * \\
(.094)\end{array}$ & $\begin{array}{l}.221 * * \\
(.093)\end{array}$ & $\begin{array}{l}.221 * * \\
(.095)\end{array}$ & $\begin{array}{l}.217 * * \\
(.097)\end{array}$ & $\begin{array}{l}.276^{* * * *} \\
(.096)\end{array}$ \\
\hline $\begin{array}{l}\text { Local unemployment } \\
\text { rate }\end{array}$ & & & $\begin{array}{l}-.393 \\
(.293)\end{array}$ & $\begin{array}{l}-.365 \\
(.282)\end{array}$ & $\begin{array}{l}-.371 \\
(.283)\end{array}$ & $\begin{array}{l}-.344 \\
(.284)\end{array}$ \\
\hline $\begin{array}{l}\text { Area-specific index of } \\
\text { industrial specialization } \\
\text { in the Nuts } 2 \text { area }\end{array}$ & & & & $\begin{array}{l}-.314^{*} \\
(.176)\end{array}$ & $\begin{array}{l}-.333^{*} \\
(.198)\end{array}$ & $\begin{array}{c}-.406 * * \\
(.200)\end{array}$ \\
\hline $\begin{array}{l}\text { Average firm size in the } \\
\text { Nuts } 2 \text { area }\end{array}$ & & & & & $\begin{array}{l}-.008 \\
(.027)\end{array}$ & $\begin{array}{l}.062 * * \\
(.030)\end{array}$ \\
\hline $\begin{array}{l}\text { Average firm size* } \log \\
\text { density }\end{array}$ & & & & & & $\begin{array}{c}.037 * * * \\
(.012)\end{array}$ \\
\hline Nuts 1 dummies & Yes & Yes & Yes & Yes & Yes & Yes \\
\hline Number of observations & 231 & 231 & 231 & 231 & 231 & 231 \\
\hline Pseudo R squared & .762 & .767 & .770 & .774 & .774 & .781 \\
\hline
\end{tabular}

Note: see Table 2 
Table 5. Probit estimates of the probability of employer - provided training. Random effects. Dependent variable: $\mathrm{T}$

\begin{tabular}{|c|c|c|c|c|c|c|}
\hline & (1) & (2) & (3) & (4) & (5) & (6) \\
\hline Age & $\begin{array}{c}-.045^{* * * *} \\
(.013)\end{array}$ & $\begin{array}{c}-.045 * * * \\
(.013)\end{array}$ & $\begin{array}{c}-.045 * * * \\
(.013)\end{array}$ & $\begin{array}{c}-.044 * * * \\
(.013)\end{array}$ & $\begin{array}{c}-.044 * * * \\
(.013)\end{array}$ & $\begin{array}{c}-.044 * * * \\
(.013)\end{array}$ \\
\hline Age squared & $\begin{array}{l}.000 * * \\
(.000)\end{array}$ & $\begin{array}{l}.000 * * \\
(.000)\end{array}$ & $\begin{array}{l}.000 * * \\
(.000)\end{array}$ & $\begin{array}{l}.000 * * \\
(.000)\end{array}$ & $\begin{array}{l}.000 * * \\
(.000)\end{array}$ & $\begin{array}{l}.000 * * \\
(.000)\end{array}$ \\
\hline Gender & $\begin{array}{l}.101 * * \\
(.046)\end{array}$ & $\begin{array}{l}.101 * * \\
(.046)\end{array}$ & $\begin{array}{l}.101^{* *} \\
(.046)\end{array}$ & $\begin{array}{l}.100 * * \\
(.046)\end{array}$ & $\begin{array}{l}.100 * * \\
(.046)\end{array}$ & $\begin{array}{l}.100 * * \\
(.046)\end{array}$ \\
\hline Medium-sized firm & $\begin{array}{l}.187 * * * \\
(.055)\end{array}$ & $\begin{array}{c}.187 * * * \\
(.055)\end{array}$ & $\begin{array}{l}.187 * * * \\
(.055)\end{array}$ & $\begin{array}{c}.187 * * * \\
(.055)\end{array}$ & $\begin{array}{l}.187 * * * \\
(.055)\end{array}$ & $\begin{array}{c}.187 * * * \\
(.055)\end{array}$ \\
\hline Large-sized firm & $\begin{array}{l}.323 * * * \\
(.040)\end{array}$ & $\begin{array}{l}.323 * * * \\
(.040)\end{array}$ & $\begin{array}{l}.323 * * * \\
(.040)\end{array}$ & $\begin{array}{l}.325 * * * \\
(.040)\end{array}$ & $\begin{array}{l}.325 * * * \\
(.040)\end{array}$ & $\begin{array}{l}.325 * * * \\
(.040)\end{array}$ \\
\hline $\begin{array}{l}\text { High School and } \\
\text { college degree }\end{array}$ & $\begin{array}{l}.318 * * * \\
(.042)\end{array}$ & $\begin{array}{l}.318 * * * \\
(.042)\end{array}$ & $\begin{array}{l}.318 * * * \\
(.042)\end{array}$ & $\begin{array}{l}.317 * * * \\
(.042)\end{array}$ & $\begin{array}{l}.317 * * * \\
(.042)\end{array}$ & $\begin{array}{c}.317 * * * \\
(.042)\end{array}$ \\
\hline Married & $\begin{array}{l}.208 * * * \\
(.045)\end{array}$ & $\begin{array}{l}.208 * * * \\
(.045)\end{array}$ & $\begin{array}{l}.208 * * * \\
(.045)\end{array}$ & $\begin{array}{l}.206 * * * \\
(.045)\end{array}$ & $\begin{array}{l}.206 * * * \\
(.045)\end{array}$ & $\begin{array}{l}.206 * * * \\
(.045)\end{array}$ \\
\hline $\begin{array}{l}\text { Log employment } \\
\text { density in the Nuts } 2 \\
\text { area }\end{array}$ & $\begin{array}{l}-.099 * * * \\
\quad(.028)\end{array}$ & $\begin{array}{c}-.099 * * * \\
\quad(.028)\end{array}$ & $\begin{array}{c}-.082 * * * \\
\quad(.039)\end{array}$ & $\begin{array}{c}-.091 * * \\
(.040)\end{array}$ & $\begin{array}{c}-.088 * * \\
(.040)\end{array}$ & $\begin{array}{l}-.486^{*} \\
(.252)\end{array}$ \\
\hline $\begin{array}{l}\text { Percentage of college } \\
\text { graduates in the Nuts } 2 \\
\text { area }\end{array}$ & & $\begin{array}{l}.475 \\
(.615)\end{array}$ & $\begin{array}{l}.575 \\
(.635)\end{array}$ & $\begin{array}{l}.703 \\
(.640)\end{array}$ & $\begin{array}{l}.855 \\
(.662)\end{array}$ & $\begin{array}{l}1.081 \\
(.676)\end{array}$ \\
\hline $\begin{array}{l}\text { Local unemployment } \\
\text { rate }\end{array}$ & & & $\begin{array}{l}-1.045 \\
(1.669)\end{array}$ & $\begin{array}{c}-.810 \\
(1.673)\end{array}$ & $\begin{array}{c}-.417 \\
(1.727)\end{array}$ & $\begin{array}{c}-.404 \\
(1.726)\end{array}$ \\
\hline $\begin{array}{l}\text { Area - specific index } \\
\text { of industrial } \\
\text { specialization in the } \\
\text { Nuts } 2 \text { area }\end{array}$ & & & & $\begin{array}{c}-2.110 * * \\
(1.035)\end{array}$ & $\begin{array}{l}-1.830^{*} \\
(1.079)\end{array}$ & $\begin{array}{l}-1.990 * \\
(1.082)\end{array}$ \\
\hline $\begin{array}{l}\text { Average firm size in } \\
\text { the Nuts } 2 \text { area }\end{array}$ & & & & & $\begin{array}{l}.150 * \\
(.163)\end{array}$ & $\begin{array}{l}.339 * \\
(.201)\end{array}$ \\
\hline $\begin{array}{l}\text { Average firm size*log } \\
\text { density }\end{array}$ & & & & & & $\begin{array}{l}.132 \\
(.082)\end{array}$ \\
\hline $\begin{array}{l}\text { Standard deviation of } \\
\text { unobserved individual } \\
\text { effect }\end{array}$ & $\begin{array}{l}.901 \\
(.028)\end{array}$ & $\begin{array}{l}.901 \\
(.028)\end{array}$ & $\begin{array}{l}.900 \\
(.028)\end{array}$ & $\begin{array}{l}.901 \\
(.028)\end{array}$ & $\begin{array}{l}.901 \\
(.028)\end{array}$ & $\begin{array}{l}.900 \\
(.028)\end{array}$ \\
\hline Nuts 1 dummies & Yes & Yes & Yes & Yes & Yes & Yes \\
\hline $\begin{array}{l}\text { Number of } \\
\text { observations }\end{array}$ & 16770 & 16770 & 16770 & 16770 & 16770 & 16770 \\
\hline Log likelihood & -7040.9 & -7040.6 & -7040.4 & -7038.3 & -7037.8 & -7036.6 \\
\hline
\end{tabular}

Note: see Table 2 
Table 6. Probit estimates of the probability of voluntary turnover. Pooled cross section time series data. Average partial effects. Dependent variable: a dummy equal to 1 in the event of voluntary turnover and to zero otherwise.

\begin{tabular}{|l|c|}
\hline & $(1)$ \\
\hline \hline Tenure*100 & $\begin{array}{c}.413 * * * \\
(.064)\end{array}$ \\
\hline \hline Gender*100 & -.009 \\
& $(.026)$ \\
\hline \hline High School and college degrees*100 & -.009 \\
& $(.027)$ \\
\hline \hline Married*100 & $.137 * * *$ \\
& $(.032)$ \\
\hline \hline Training in the previous period*100 & -.005 \\
& $(.039)$ \\
\hline Training in the previous period * High & $.128 * *$ \\
density*100 & $(.071)$ \\
\hline \hline & 9482 \\
\hline Number of observations & .307 \\
\hline Pseudo R squared & \\
\hline
\end{tabular}

Note: See Table 2. 
Table 7. Probit estimates of the probability of employer provided training. Pooled cross section time series data. Average partial effects. With measures of industrial specialization and diversity. Dependent variable: $\mathrm{T}$

\begin{tabular}{|c|c|c|c|c|}
\hline & (1) & (2) & (3) & (4) \\
\hline Age & $\begin{array}{c}-.005^{* *} \\
(.002)\end{array}$ & $\begin{array}{c}-.005 * * \\
(.002)\end{array}$ & $\begin{array}{c}-.005 * * \\
(.002)\end{array}$ & $\begin{array}{l}-.005 * * \\
(.002)\end{array}$ \\
\hline Age squared & $\begin{array}{l}.000 \\
(.000)\end{array}$ & $\begin{array}{l}.000 \\
(.000)\end{array}$ & $\begin{array}{l}.000 \\
(.000)\end{array}$ & $\begin{array}{l}.000 \\
(.000)\end{array}$ \\
\hline Gender & $\begin{array}{l}.017 * * \\
(.008)\end{array}$ & $\begin{array}{l}.017 * * \\
(.008)\end{array}$ & $\begin{array}{l}.019 * * \\
(.008)\end{array}$ & $\begin{array}{l}.019 * * \\
(.008)\end{array}$ \\
\hline Medium-sized firm & $\begin{array}{c}.038 * * * \\
(.012)\end{array}$ & $\begin{array}{c}.038 * * * \\
(.012)\end{array}$ & $\begin{array}{l}.019 \\
(.013)\end{array}$ & $\begin{array}{l}.019 \\
(.013)\end{array}$ \\
\hline Large-sized firm & $\begin{array}{l}.078 * * * \\
(.007)\end{array}$ & $\begin{array}{l}.078 * * * \\
(.007)\end{array}$ & $\begin{array}{c}.062 * * * \\
(.008)\end{array}$ & $\begin{array}{c}.062 * * * \\
(.008)\end{array}$ \\
\hline High School and college degrees & $\begin{array}{c}.073 * * * \\
(.007)\end{array}$ & $\begin{array}{c}.073 * * * \\
(.007)\end{array}$ & $\begin{array}{c}.070 * * * \\
(.008)\end{array}$ & $\begin{array}{c}.070 * * * \\
(.008)\end{array}$ \\
\hline Married & $\begin{array}{l}.041 * * * \\
(.007)\end{array}$ & $\begin{array}{l}.041 * * * \\
(.007)\end{array}$ & $\begin{array}{l}.034 * * * \\
(.008)\end{array}$ & $\begin{array}{l}.034 * * * \\
(.008)\end{array}$ \\
\hline $\begin{array}{l}\text { Area and industry specific index of } \\
\text { industrial specialization }\end{array}$ & $\begin{array}{l}-.106 * * \\
(.048)\end{array}$ & $\begin{array}{l}-.129 \\
(.091)\end{array}$ & $\begin{array}{l}-.149 * * * \\
\quad(.051)\end{array}$ & $\begin{array}{l}-.212 * * \\
(.099)\end{array}$ \\
\hline $\begin{array}{l}\text { Area and industry specific index of } \\
\text { industrial diversity }\end{array}$ & & $\begin{array}{l}.001 \\
(.002)\end{array}$ & & $\begin{array}{c}.002 \\
(.002)\end{array}$ \\
\hline Regional dummies & Yes & Yes & Yes & Yes \\
\hline Number of observations & 13846 & 13846 & 10181 & 10181 \\
\hline Pseudo R squared & .114 & .114 & .104 & .104 \\
\hline
\end{tabular}

Note: the estimates in the former two columns are for all occupational groups. The estimates in the last two columns exclude managerial and professional jobs. Each regression includes a constant, year and occupational dummies. Cluster adjusted robust standard errors. One, two and three stars when the coefficients are significantly different from zero at the 10,5 and 1 percent level of confidence. 
Table 8. Probit estimates of the probability of employer - provided training. Pooled cross section time series data. Average partial effects. Robustness checks: 1994-97 only, age 25 to 54 only, lagged dependent variable and broader definition of training. Dependent variable: $\mathrm{T}$

\begin{tabular}{|c|c|c|c|c|}
\hline & (1) & (2) & (3) & (4) \\
\hline Age & $\begin{array}{c}-.006^{* *} \\
(.003)\end{array}$ & $\begin{array}{l}-.001 \\
(.026)\end{array}$ & $\begin{array}{l}-.005^{*} \\
(.003)\end{array}$ & $\begin{array}{c}-.027 * * * \\
(.002)\end{array}$ \\
\hline Age squared & $\begin{array}{l}.000 \\
(.000)\end{array}$ & $\begin{array}{l}.000 \\
(.000)\end{array}$ & $\begin{array}{l}.000 \\
(.000)\end{array}$ & $\begin{array}{l}.000 * * * \\
(.000)\end{array}$ \\
\hline Gender & $\begin{array}{c}.032 * * * \\
(.010)\end{array}$ & $\begin{array}{l}.026^{* * * *} \\
(.007)\end{array}$ & $\begin{array}{l}.013 \\
(.009)\end{array}$ & $\begin{array}{l}.025^{* * *} \\
(.007)\end{array}$ \\
\hline Medium-sized firm & $\begin{array}{l}.043 * * \\
(.018)\end{array}$ & $\begin{array}{c}.037 * * * \\
(.013)\end{array}$ & $\begin{array}{l}.024 \\
(.015)\end{array}$ & $\begin{array}{l}.052 * * * \\
(.013)\end{array}$ \\
\hline Large-sized firm & $\begin{array}{c}.111 * * * \\
(.010)\end{array}$ & $\begin{array}{l}.091 * * * \\
(.008)\end{array}$ & $\begin{array}{c}.070 * * * \\
(.009)\end{array}$ & $\begin{array}{c}.096 * * * \\
(.008)\end{array}$ \\
\hline High school and college degree & $\begin{array}{l}.053 * * * \\
(.009)\end{array}$ & $\begin{array}{l}.072 * * * \\
(.006)\end{array}$ & $\begin{array}{c}.083 * * * \\
(.010)\end{array}$ & $\begin{array}{l}.092 * * * \\
(.006)\end{array}$ \\
\hline Married & $\begin{array}{l}.044 * * * \\
(.010)\end{array}$ & $\begin{array}{c}.034 * * * \\
(.013)\end{array}$ & $\begin{array}{l}.013 \\
(.009)\end{array}$ & $\begin{array}{l}.042^{* * * *} \\
(.013)\end{array}$ \\
\hline $\begin{array}{l}\text { Log employment density in the } \\
\text { Nuts } 2 \text { area }\end{array}$ & $\begin{array}{c}-.095 * * \\
(.042)\end{array}$ & $\begin{array}{l}-.110 * * * \\
(.037)\end{array}$ & $\begin{array}{l}-.153 * * * \\
\quad(.048)\end{array}$ & $\begin{array}{l}-.100 * * * \\
\quad(.040)\end{array}$ \\
\hline $\begin{array}{l}\text { Percentage of college graduates } \\
\text { in the Nuts } 2 \text { area }\end{array}$ & $\begin{array}{l}.232 * \\
(.122)\end{array}$ & $\begin{array}{l}.340 * * * \\
(.101)\end{array}$ & $\begin{array}{l}.162 \\
(.120)\end{array}$ & $\begin{array}{l}.144 \\
(.111)\end{array}$ \\
\hline Local unemployment rate & $\begin{array}{l}-.376 \\
(.371)\end{array}$ & $\begin{array}{l}-.427 \\
(.308)\end{array}$ & $\begin{array}{l}-.433 \\
(.380)\end{array}$ & $\begin{array}{l}-.093 \\
(.330)\end{array}$ \\
\hline $\begin{array}{l}\text { Area- specific index of } \\
\text { industrial specialization in the } \\
\text { Nuts } 2 \text { area }\end{array}$ & $\begin{array}{l}-.310 \\
(.262)\end{array}$ & $\begin{array}{l}-.349 \\
(.221)\end{array}$ & $\begin{array}{l}-.532 * \\
(.251)\end{array}$ & $\begin{array}{l}-.499 * \\
(.235)\end{array}$ \\
\hline $\begin{array}{l}\text { Average firm size in the Nuts } 2 \\
\text { area }\end{array}$ & $\begin{array}{l}.038 \\
(.030)\end{array}$ & $\begin{array}{l}.095 * * * \\
(.028)\end{array}$ & $\begin{array}{l}.063^{*} \\
(.036)\end{array}$ & $\begin{array}{l}.061 * * \\
(.028)\end{array}$ \\
\hline Average size*log density & $\begin{array}{l}.027 * * \\
(.013)\end{array}$ & $\begin{array}{c}.034 * * * \\
(.012)\end{array}$ & $\begin{array}{c}.049 * * * \\
(.015)\end{array}$ & $\begin{array}{l}.027 * * \\
(.013)\end{array}$ \\
\hline Nuts 1 dummies & Yes & Yes & Yes & Yes \\
\hline Number of observations & 10064 & 13601 & 10947 & 18047 \\
\hline Adjusted R squared & .086 & .132 & .236 & .106 \\
\hline
\end{tabular}

Note: see Table 2. 
Table 9. Probit estimates of the probability of employer - provided training. Pooled cross section time series data. Average partial effects. With alternative measures of density. Dependent variable: $\mathrm{T}$

\begin{tabular}{|c|c|c|}
\hline & (1) & (2) \\
\hline Age & $\begin{array}{c}-.008 * * * \\
(.002)\end{array}$ & $\begin{array}{c}-.008 * * * \\
(.002)\end{array}$ \\
\hline Age squared & $\begin{array}{l}.000 * * * \\
(.000)\end{array}$ & $\begin{array}{c}.000 * * * \\
(.000)\end{array}$ \\
\hline Gender & $\begin{array}{l}.022 * * * \\
(.007)\end{array}$ & $\begin{array}{c}.021 * * * \\
(.007)\end{array}$ \\
\hline Medium-sized firm & $\begin{array}{c}.038^{* * * *} \\
(.012)\end{array}$ & $\begin{array}{l}.038^{* *} \\
(.012)\end{array}$ \\
\hline Large-sized firm & $\begin{array}{l}.079 * * * \\
(.007)\end{array}$ & $\begin{array}{c}.078 * * * \\
(.007)\end{array}$ \\
\hline High School and college degree & $\begin{array}{c}.065 * * * \\
(.007)\end{array}$ & $\begin{array}{c}.067 * * * \\
(.007)\end{array}$ \\
\hline Married & $\begin{array}{l}.036 * * * \\
(.006)\end{array}$ & $\begin{array}{c}.036 * * * \\
(.006)\end{array}$ \\
\hline Log employment density in the Nuts 2 area & $\begin{array}{c}-.106 * * * \\
(.031)\end{array}$ & $\begin{array}{l}-.093 * * * \\
(.025)\end{array}$ \\
\hline Local unemployment rate & $\begin{array}{l}-.443 * * \\
(.219)\end{array}$ & $\begin{array}{l}-.432 * \\
(.256)\end{array}$ \\
\hline $\begin{array}{l}\text { Percentage of college graduates in the Nuts } 2 \\
\text { area }\end{array}$ & $\begin{array}{l}.331 * * * \\
(.053)\end{array}$ & $\begin{array}{l}.309 * * * \\
(.098)\end{array}$ \\
\hline $\begin{array}{l}\text { Area - specific index of industrial } \\
\text { specialization in the Nuts } 2 \text { area }\end{array}$ & $\begin{array}{l}-.503 * * * \\
\quad(.180)\end{array}$ & $\begin{array}{l}-.297 \\
(.192)\end{array}$ \\
\hline Average firm size in the Nuts 2 area & $\begin{array}{l}.057 * * * \\
(.019)\end{array}$ & $\begin{array}{l}.085 * * * \\
(.027)\end{array}$ \\
\hline Average firm size $* \log$ density & $\begin{array}{c}.032 * * * \\
(.009)\end{array}$ & $\begin{array}{c}.027 * * * \\
(.008)\end{array}$ \\
\hline Nuts 1 dummies & Yes & Yes \\
\hline Number of observations & 16770 & 16770 \\
\hline Pseudo R squared & .116 & .116 \\
\hline
\end{tabular}

Note: alternative measure of density in column (1); skilled density in column (2). Each regression includes a constant, year, industry, occupational dummies and dummies for regions affected by EU Objective 1 and Objective 2 structural funds. Cluster adjusted robust standard errors. One, two and three stars when the coefficients are significantly different from zero at the 10, 5 and 1 percent level of confidence respectively. 
Table 10. Probit estimates of the probability of employer provided training. Pooled cross section time series data. Average partial effects. With the density of neighboring areas. Dependent variable: $\mathrm{T}$

\begin{tabular}{|c|c|c|}
\hline & (1) & (2) \\
\hline Age & $\begin{array}{c}-.008 * * * \\
(.002)\end{array}$ & $\begin{array}{l}-.008 * * * \\
(.002)\end{array}$ \\
\hline Age squared & $\begin{array}{c}.000 * * * \\
(.000)\end{array}$ & $\begin{array}{c}.000 * * * \\
(.000)\end{array}$ \\
\hline Gender & $\begin{array}{l}.022 * * * \\
(.007)\end{array}$ & $\begin{array}{l}.021 * * * \\
(.007)\end{array}$ \\
\hline Medium-sized firm & $\begin{array}{l}.038 * * \\
(.012)\end{array}$ & $\begin{array}{l}.038 * * \\
(.012)\end{array}$ \\
\hline Large-sized firm & $\begin{array}{l}.080 * * * \\
(.007)\end{array}$ & $\begin{array}{l}.080 * * * \\
(.007)\end{array}$ \\
\hline High School and college degree & $\begin{array}{l}.065 * * * \\
(.007)\end{array}$ & $\begin{array}{l}.067 * * * \\
(.007)\end{array}$ \\
\hline Married & $\begin{array}{c}.035 * * * \\
(.006)\end{array}$ & $\begin{array}{l}.035 * * * \\
(.006)\end{array}$ \\
\hline Log employment density in the Nuts 2 area & $\begin{array}{l}-.170 * * * \\
\quad(.047)\end{array}$ & $\begin{array}{c}-.083 * * \\
(.036)\end{array}$ \\
\hline $\begin{array}{l}\text { Log employment density in the neighboring } \\
\text { areas }\end{array}$ & & $\begin{array}{c}-.016 * * \\
(.006)\end{array}$ \\
\hline Local unemployment rate & $\begin{array}{l}-.299 \\
(.235)\end{array}$ & $\begin{array}{c}-.361 \\
(.267)\end{array}$ \\
\hline $\begin{array}{l}\text { Percentage of college graduates in the Nuts } 2 \\
\text { area }\end{array}$ & $\begin{array}{l}.238 * * * \\
(.096)\end{array}$ & $\begin{array}{l}.218 * * \\
(.098)\end{array}$ \\
\hline $\begin{array}{l}\text { Area - specific index of industrial } \\
\text { specialization in the Nuts } 2 \text { area }\end{array}$ & $\begin{array}{c}-.375^{*} \\
(.192)\end{array}$ & $\begin{array}{c}-.407 * * \\
(.196)\end{array}$ \\
\hline Average firm size in the Nuts 2 area & $\begin{array}{c}.079 * * * \\
(.032)\end{array}$ & $\begin{array}{c}.041 \\
(.029)\end{array}$ \\
\hline Average firm size $*$ log density & $\begin{array}{c}.048 * * * \\
(.016)\end{array}$ & $\begin{array}{l}.023 * * \\
(.011)\end{array}$ \\
\hline Nuts 1 dummies & Yes & Yes \\
\hline Number of observations & 16770 & 16770 \\
\hline Pseudo R squared & .116 & .116 \\
\hline
\end{tabular}

Note: the average measure of density the first two columns and the two measures of density (local and neighboring area) in the last two columns. Each regression includes a constant, year, industry, occupational dummies and dummies for regions affected by EU Objective 1 and Objective 2 structural funds. Cluster adjusted robust standard errors. One, two and three stars when the coefficients are significantly different from zero at the 10, 5 and 1 percent level of confidence respectively. 